\title{
Effect of Citrus floral extracts on the foraging behavior of the stingless bee Scaptotrigona pectoralis (Dalla Torre)
}

\author{
Julieta Grajales-Conesa ${ }^{1}$, Virginia Meléndez Ramírez ${ }^{1}$ Leopoldo Cruz-López ${ }^{2,3}$ \& Daniel Sánchez Guillén²
}

${ }^{1}$ Universidad Autónoma de Yucatán. Campus de Ciencias Biológicas y Agropecuarias. Km 15.5 carretera Merida-Xmatkuil, A.P. 4-116 Col. Itzimná, 97100. Mérida, Yucatán, Mexico. grajales79@yahoo.com.mx; virmelen@uady.mx

${ }^{2}$ El Colegio de la Frontera Sur. Unidad Tapachula. Carretera Antiguo Aeropuerto, Km. 2.5, Tapachula, Chiapas, Mexico, 30700. Mexico. lcruz@ecosur.mx; dsanchez@ecosur.mx

${ }^{3}$ Corresponding author: 1cruz@ecosur.mx

\begin{abstract}
Effect of Citrus floral extracts on the foraging behavior of the stingless bee Scaptotrigona pectoralis (Dalla Torre) Stingless bees have an important role as pollinators of many wild and cultivated plant species in tropical regions. Little is known, however, about the interaction between floral fragrances and the foraging behavior of meliponine species. Thus we investigated the chemical composition of the extracts of citric (lemon and orange) flowers and their effects on the foraging behavior of the stingless bee Scaptotrigona pectoralis. We found that each type of flower has its own specific blend of major compounds: limonene (62.9\%) for lemon flowers, and farnesol (26.5\%), (E)-nerolidol (20.8\%), and linalool (12.7\%) for orange flowers. In the foraging experiments the S. pectoralis workers were able to use the flower extracts to orient to the food source, overlooking plates baited with hexane only. However, orange flower extracts were seemingly more attractive to these worker bees, maybe because of the particular blend present in it. Our results reveal that these fragrances are very attractive to S. pectoralis, so we can infer that within citric orchards they could be important visitors in the study area; however habitat destruction, overuse of pesticides and the competitive override by managed honeybees might have put at risk their populations and thus the ecological services they provide to us.
\end{abstract}

KEYWORDS. Citrus; foraging; flower volatiles; Scaptotrigona pectoralis; stingless bee.

RESUMO. Extratos florais de Citrus no comportamento de forrageamento da abelha sem ferrão Scaptotrigona pectoralis (Dalla Torre). As abelhas sem ferrão têm um papel importante na polinização de muitas espécies de plantas nativas e plantas cultivadas em regiões tropicais. Pouco se sabe, no entanto, sobre a interação entre as fragrâncias florais e comportamento de forrageamento de espécies de meliponíneos. Assim, investigou-se a composição química dos extratos de cítricos florais (limão e laranja) e seus efeitos sobre o comportamento de forrageamento da abelha sem ferrão Scaptotrigona pectoralis. Nós descobrimos que cada tipo de flor tem a sua própria composição específica de mistura de compostos: limoneno $(62,9 \%)$, e farnesol $(26,5 \%)$ para flores de limão, (E)-nerolidol (20,8\%), e linalol (12,7\%) para flores de laranja. Nos experimentos de forrageamento, as operárias de S. pectoralis foram capazes de utilizar os extratos de flores para se orientarem até a fonte de alimento, não sendo atrapalhadas por placas com iscas apenas de hexano. No entanto, os extratos de flores de laranja foram aparentemente mais atraentes para essas abelhas operárias, talvez por causa da mistura particular do extrato. Nossos resultados revelam que essas fragrâncias são muito atraentes para $S$. pectoralis, assim pode-se inferir que dentro de pomares cítricos poderiam ser visitantes importantes na área de estudo; no entanto a destruição do habitat, o uso excessivo de pesticidas e a substituição competitiva por abelhas Apis poderia por em risco suas populações e, assim, os serviços ecológicos que prestam para nós.

PALAVRAS-CHAVE. Abelha sem ferrão; Citrus; forrageamento; voláteis de flores; Scaptotrigona pectoralis.

Bees are considered important pollinators of both wild and cultivated flowering plant species (McGregor 1976; Roubik 1995; Slaa et al. 2006). They use the color, shape, and odor of flowers as signals to facilitate the recognition of rewarding resources. Odors provide the most important signal, though, since the chemosensory machinery of insects is evolutionary selected to have the lowest noise to signal ratio in this channel (Leal 2005). Thus it becomes relevant to investigate the composition of floral volatiles and how bees use them to recruit to profitable resources. In stingless bees (Apidae, Meliponini), for example, McCabe \& Farina (2010) showed that, while inside the colony, Melipona quadrifasciata (Lepeletier, 1836) naive foragers were able to associate floral scents with resources, using this information to make discrimination tasks during foraging outside the colony. Reichle et al. (2010) found similar results with Scaptotrigona pectoralis (Dalla Torre, 1896), showing that naïve workers could learn a series of mixtures of odors (linalool/phenylacetaldehyde, geraniol/eugenol) from the nest atmosphere, preferring in subsequent multiple choice tasks feeders baited with the learned odor. Therefore, studies of floral scents and their chemical profiles are important to increase our knowledge about the chemical bases of plant-animal relationships and pollination ecology (Flamini et al. 2003; Grajales-Conesa et al. 2011).

Among cultivated flowering plants, citrics are important crops around the world, being flowers known for producing pleasant fragrances; however little effort has been done to elucidate the identity of these volatiles (Flamini et al. 2003; Flamini et al. 2007; Jabalpurwala et al. 2009) even more, there are no studies to our knowledge aimed to investigate the inter- 
action of these fragrances with foraging bees, whose pollination service promotes fruit set and higher yields. In general, the pollination of citrics is mostly done by managed Apis mellifera (Chacoff \& Aizen 2006; Grajales-Conesa et al. 2009), though some wild native bees also take part (Roubik 1995; Slaa et al. 2006), such as Trigona biroi (Firese, 1898) in calamondin (Cervancia \& Manila, 2000 in Slaa et al. 2006), Nannotrigona perilampoides (Creson, 1878), S. pectoralis on flowers of orange and lemon (pers. obs.), Geotrigona argentina (Camargo \& Moure, 1996) and Tetragonisca angustula (Latreille, 1811) on pomelo (Chacoff \& Aizen 2006).

The overwhelming abundance of feral and managed exotic honeybees in some areas might have forced native bees to change their floral preferences toward less profitable plant species, thus probably affecting their populations (Villanueva et al. 2005). The city of Oxkutzcab in Yucatan, Mexico, our study site, is by no means an exception to this situation: some studies showed that $98 \%$ of bees collected in this site corresponded to managed $A$. mellifera, and only $2 \%$ to non-managed native bees (Grajales-Conesa et al. 2009).

In addition to the possible food depletion by exploitative competition, it is likely that food odor-marking by honeybees elicits an evasive response in later visitors, as shown by Gawleta et al. (2005) and Goulson et al. (1998), though this behavior can also be context dependant (Sanchez et al. 2008). In the same sense, plant volatiles can elicit repellent responses in honeybees (Henning et al. 1992), though this has not been studied with stingless bees and citric volatiles. In this work we thus aimed to understand the interaction between citric floral odors and S. pectoralis (Apidae, Meliponini), an important species in pollination ecology (Meléndez-Ramírez et al. 2002; Slaa et al. 2006), besides its presence within the orchard on orange and lemon flowers and its abundance in the study area (p. obs). Therefore, we performed this work by, a) identifying the major components of orange and lemon flower volatiles, and b) investigating whether workers of $S$. pectoralis are attracted to orange and lemon floral volatiles and how they exploit and move between patches over time.

\section{MATERIAL AND METHODS}

Study site and bee colonies. Orange and lemon flowers were collected from the orchards of Oxkutzcab, Yucatán, Mexico, close to the Protected Area of San Juan Bautista Tabi (20¹6'19'”N, 89³0'44'W, 32 m altitude), in which predominates deciduous forest vegetation (Flores \& Espejel 1994).

Three queen right colonies of $S$. pectoralis housed in their original tree cavities located in the gardens of the Campus de Ciencias Biológicas y Agropecuarias, in the Universidad Autónoma de Yucatán, in the city of Mérida, Yucatán, Mexico, were used for the foraging experiments from September to November, 2010.

The investigation was performed in two stages. The first one consisted in collecting flower fragrances by hexane extraction followed by gas chromatography-mass spectrometry analysis of its chemical composition. The second stage aimed to describe the foraging pattern by $S$. pectoralis workers when exposed to the floral extracts previously obtained.

Extraction of volatiles. Volatiles were extracted from ten orange and ten lemon flowers collected between 9:00-11:00 am. Flowers were cut into smalls pieces and introduced in 2 $\mathrm{ml}$ of hexane for one minute; next, solids were removed and the remaining solution was kept in refrigeration $\left(-20^{\circ} \mathrm{C}\right)$ until analysis.

Chemical analysis. Gas chromatography-mass spectrometry of orange and lemon extracts was carried out with a Varian CP-3800 (Palo Alto, CA) chromatograph linked to a Varian Saturn 2200 mass spectrometer (Palo Alto, CA). The samples were analyzed using a non polar capillary column (DB-5MS, $30 \mathrm{~m} \times 0.25 \mathrm{~mm}$ i.d. $0.25 \mu \mathrm{m}$, J\&W Scientific). The oven was programmed from $50^{\circ} \mathrm{C}$ to $280^{\circ} \mathrm{C}$ at $15^{\circ} \mathrm{C} /$ min. The carrier gas was helium at $1 \mathrm{~mL} / \mathrm{min}$. Identification of the compounds was done by comparison of retention times and mass spectral data with those of synthetic compounds.

Preliminary identification of unknown compounds was carried out using the NIST 2002 spectral library or mass spectral data reported in literature. The relative percentage of the components was calculated from the sum of the recorded peaks.

Attraction of S. pectoralis to floral volatiles. These experiments comprised two sequential phases. The first phase consisted in training for 10-20 min a group of 5-10 bees to collect a $50 \% \mathrm{v} / \mathrm{v}$ honey:water solution from a plastic plate located $10 \mathrm{~m}$ away the colony, following the methodology of Sánchez et al. (2008). In the test phase we removed the training plate and placed two patches of artificial food sources, equidistant from the training location to minimize site learning bias. They were separated from each other by $2 \mathrm{~m}$. Each patch consisted of eight plastic round plates $(25 \mathrm{~cm}$ diameter) each with a yellow square piece of Styrofoam $\left(20 \mathrm{~cm}^{2}\right)$ in the center; plates were placed regularly on a $1.5 \mathrm{~m} \mathrm{x} 1.0 \mathrm{~m}$ brown wood table. Each plate of one of the patches offered $1 \mathrm{~mL}$ of a mixture of $10 \mu \mathrm{l}$ of either orange or lemon extract per $1 \mathrm{~mL}$ sucrose solution $1 \mathrm{M}$. (floral baited patch); identical proportions of hexane and food were applied to the plates of the other patch (control). We recorded the visits of bees during $35 \mathrm{~min}$ to both patches.

Three colonies were evaluated in this way: four repetitions per type of flower per colony $(\mathrm{n}=12$ for orange and lemon respectively); these repetitions and bee training were done from 9:00 to 12:00 am from September to November 2010, and during a day it was possible to make one repetition per colony.

Statistics. Chemical profiles (only those volatiles present in both type of flowers and their quantities) were subjected to a factor analysis using the nearest neighbor method and Euclidean distance as a measure (cluster analysis). Count data from the foraging experiments did not meet the assumption of normality, thus they were square root transformed before a mixed model was applied, which considered a correlation structure (repeated measures), considering days as blocks in order to control colony effect and learning. All statistical tests were run in Statistica version 7.1 (StatSoft 2005). 


\section{RESULTS}

Chemical profile. A total of 40 compounds were identified in the floral extracts of orange and lemon flowers (Table I). The major components of the lemon flowers included myrcene, $\beta$-pinene, citral, trans-ocimene, caryophyllene and limonene, being the last one the most abundant (62.9\%). In contrast we found farnesol (26.5\%), (E)-nerolidol (20.8\%), and linalool $(12.7 \%)$ to be the major compounds identified for orange extracts. The cluster analysis correctly grouped each type of flower to its corresponding cluster (Fig. 1).

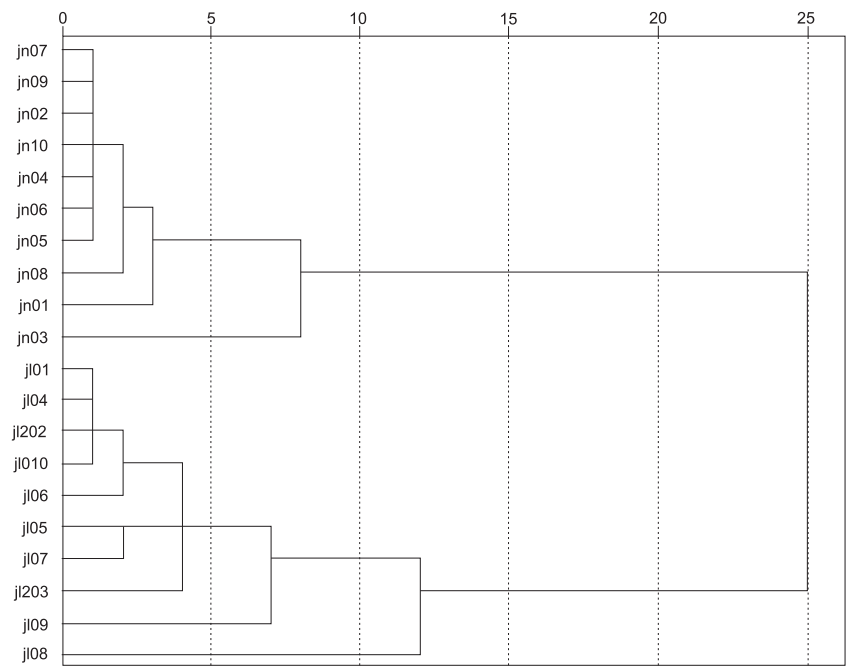

Fig. 1. Cluster analysis of volatile compounds present in orange and lemon flowers. $\mathrm{jn}=$ orange compounds, $\mathrm{jl}=$ lemon compounds.

Attraction of S. pectoralis to floral volatiles. S. pectoralis foragers visited each plate baited with the extracts of orange $(92 \pm 9.32)$ and lemon flowers $(84 \pm 4.41)$, more often than their respective controls (orange $29 \pm 1.60$ and lemon $37 \pm 4.43$ ), yielding a significant difference (orange: $\mathrm{F}=$ 131.68; $\mathrm{df}=1,17 ; \mathrm{p}<0.001$; lemon: $\mathrm{F}=54.92 ; \mathrm{df}=1,17 ; \mathrm{p}$ $<0.001$ ), as shown in Fig. 2. Additionally, the ratio of the average number of bees landing on the floral-baited plates over the control patch indicates that orange extracts were more attractive than lemon extracts (3.18 and 2.26, respectively).

\section{DISCUSSION}

Floral odors are used by foragers of highly social bees to recruit nestmates to rich food sources. These odors reach recipients either during collecting food from flowers, while receiving food from nestmates or simply by detecting them inside the colony environment (Slaa et al. 1998; Nieh 2004; Lichtenberg et al. 2010). In this study we found that citric flower scents (from orange and lemon) collected during foraging were highly attractive to foragers of the stingless bee $S$. pectoralis, eliciting a strong recruitment behavior in this species.
Chemical profile of citric flowers. We found limonene to be the major compound (62.9\%), in lemon flowers, similar to the results of Jabalpurwala et al. (2009), who found $60 \%$ of this compound in both lime and lemon. In orange flowers, farnesol (26.5\%), (E)-nerolidol (20.8\%), and linalool (12.7\%) are in relative large quantities, which were also detected in Jabalpurwala et al. (2009), but in different amounts. In this case the difference could be due to the collection technique, static headspace solid-phase microextraction vs solvent extraction in our case. Another possibility is that the differences are due to the cultivars in their study and ours. For example, studies on nine Litchi chinensis Sonn. cultivars from two areas showed differences in the volatile composition and concentration between them (Wu et al. 2009). Nonetheless, the mixtures were qualitatively similar in both their and our study.

Foraging behavior of S. pectoralis. The foragers were trained to collect honey solution from plastic plates. Recruited bees therefore were exposed to honey's odor inside the colony, this way explaining their presence in the control plates in the beginning of the test phase. However, the plates baited with floral extracts elicited the strongest attraction, which was more evident as time passed (Fig. 2 A and B). Since the colonies were in the vicinity of citric trees it is highly possible that they were previously exposed to odors from these flowers, perhaps brought in to the colonies by foragers other than our trained ones. Reichle et al. (2010) actually found that $S$. pectoralis is able to use odors from the nest atmosphere, habilitating foragers to reach food sources baited with the same scent but outside the colony. Thus when the recruits in our experiments
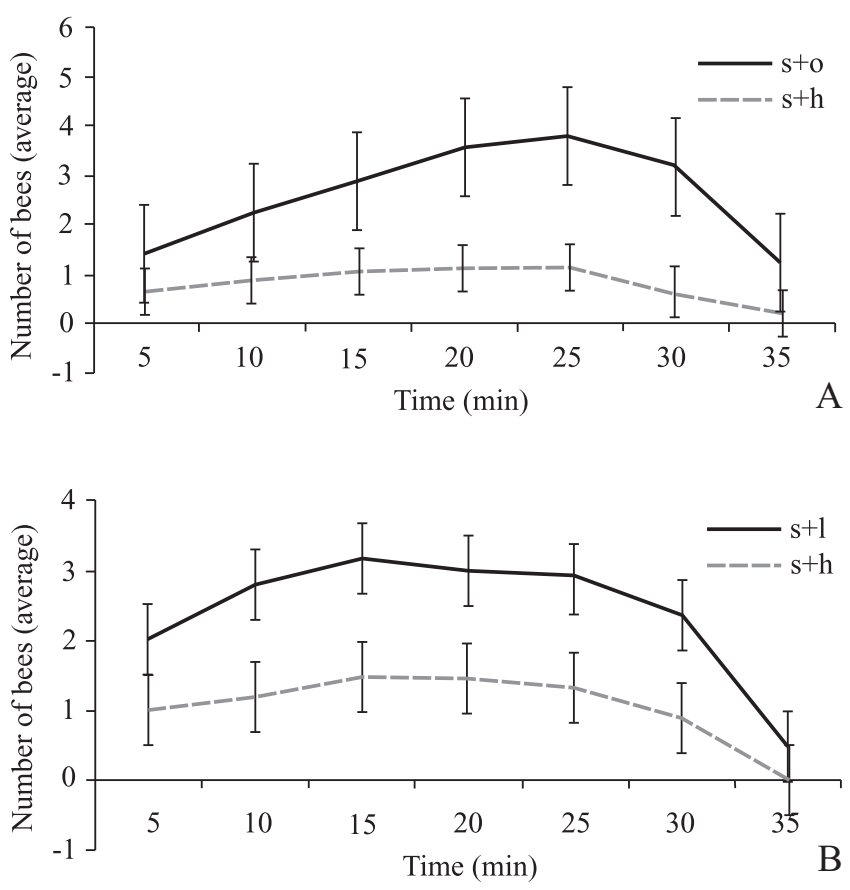

Fig. 2. Foraging pattern over time of $S$. pectoralis on patches baited and average standard deviation; A) orange extracts $(\mathrm{s}+\mathrm{o}=$ sucrose + orange extract $)$ and control $(\mathrm{s}+\mathrm{h}=$ sucrose + hexane $)$; $)$ lemon extracts $(\mathrm{s}+\mathrm{l}=$ sucrose + lemon extract) and control $(s+h)$. 
Table I. Volatiles of orange and lemon flower extracts. Listed values are the percentage of the total peak area for each extract.

\begin{tabular}{|c|c|c|c|c|}
\hline \multirow{2}{*}{ Number } & \multirow{2}{*}{ Compound } & \multirow{2}{*}{$\mathrm{KI}$} & \multicolumn{2}{|c|}{ Percentage of the total peak area } \\
\hline & & & Lemon $\mathrm{n}=10$ & Orange $n=10$ \\
\hline 1 & $\alpha$-Pinene * & 941 & 0.244 & 0.232 \\
\hline 2 & Sabinene & 980 & 0.815 & - \\
\hline 3 & $\beta$-Phellandrene & 981 & - & 2.445 \\
\hline 4 & $\beta$-Pinene * & 987 & 2.378 & 0.382 \\
\hline 5 & Myrcene * & 993 & 1.180 & 0.402 \\
\hline 6 & Limonene* & 1039 & 62.89 & 1.484 \\
\hline 7 & trans-Ocimene & 1050 & 1.745 & 0.929 \\
\hline 8 & $\gamma$-Terpinene* & 1066 & 0.421 & - \\
\hline 9 & $\mathrm{~N} / \mathrm{id}$ & 1081 & - & 0.252 \\
\hline 10 & Linalool* & 1105 & - & 12.727 \\
\hline 11 & N/id & 1123 & - & 1.457 \\
\hline 12 & Terpineol* & 1209 & 0.651 & - \\
\hline 13 & $\alpha$-Terpineol & 1214 & - & 0.248 \\
\hline 14 & Nerol* ${ }^{*}$ & 1233 & 0.659 & - \\
\hline 15 & Neral* & 1247 & 4.287 & - \\
\hline 16 & Geranial* & 1276 & 6.545 & - \\
\hline 17 & Indol & 1282 & - & 1.997 \\
\hline 18 & N/id & 1317 & - & 4.035 \\
\hline 19 & $\sigma$-Elemene & 1348 & 0.958 & - \\
\hline 20 & N/id & 1363 & - & 11.731 \\
\hline 21 & p-Elemene & 1403 & 1.683 & 3.715 \\
\hline 22 & $\beta$-Caryophyllene* & 1443 & 2.792 & - \\
\hline 23 & (Z)- $\beta$-Farnesene & 1444 & - & 0.678 \\
\hline 24 & N/id & 1447 & - & 1.196 \\
\hline 25 & (E)- $\beta$-Farnesene & 1458 & 0.561 & 2.180 \\
\hline 26 & $\alpha$-Caryophyllene & 1479 & 0.172 & - \\
\hline 27 & p-Cubebene & 1504 & 0.755 & - \\
\hline 28 & $\alpha$-Farnesene & 1510 & 1.108 & - \\
\hline 29 & $(\mathrm{E}, \mathrm{E})-\alpha$-Farnesene & 1511 & - & 0.391 \\
\hline 30 & Sesquiterpene 1 & 1520 & 1.305 & - \\
\hline 31 & (Z)-Nerolidol & 1539 & - & 0.146 \\
\hline 32 & (E)-Nerolidol & 1569 & - & 20.817 \\
\hline 33 & N/id & 1605 & - & 0.581 \\
\hline 34 & Sesquiterpene 2 & 1648 & 0.414 & - \\
\hline 35 & N/id & 1664 & - & 0.430 \\
\hline 36 & N/id & 1680 & - & 3.687 \\
\hline 37 & Sesquiterpene 3 & 1697 & 3.810 & - \\
\hline 38 & Heptadecane & 1699 & - & 1.412 \\
\hline 39 & Farnesol * & 1726 & - & 26.498 \\
\hline 40 & $(\mathrm{E}, \mathrm{Z})$-Farnesol & 1747 & 1.747 & - \\
\hline
\end{tabular}

*Volatiles identified with synthetic compounds. N/id = not identified. KI = Kovats Index.

found the patches, they readily approached the ones baited with floral extracts. In addition, the honey solution was mixed with the extracts, thus reinforcing the effect of the odors trough trophallaxis. Even though recruits could also choose the baited patches by following field information from nestmates (Schmidt et al. 2003; Slaa et al. 2003), we think this is unlikely. We used clean, odorless plates in both patches during the test phase, and the average number of bees observed during the first minutes was similar in both floral and hexane baited plates, allowing for a similar recruitment pattern in both patches by either odor marking or social facilitation. Recruits were effectively attracted to floral scents, with a negligible effect of recruitment information, if any.

In order to observe how recruits exploited the patches over time we let them to deplete the food on each plate. Interestingly the recruits did not switch to the control patches despite it was evident that the food was scant in the floral baited plates approximately $30 \mathrm{~min}$ after the beginning of the test phase. This is a very interesting finding, since several studies have shown that switching between food sources, when one is depleted, is not a rare event (Sánchez et al. 2009). Distance could not be an impediment to switching between patches, since they were apart by $2 \mathrm{~m}$. In addition, many of the bees were familiarized with the physical characteristics of the floral baited patch, which were identical to the control's and could facilitate the switching (Sánchez et al. 2009). Why did they not move to the more profitable, control patch? We observed that after the end of the test phase bees were still trying to collect food from the floral baited patch, searching plate by plate. Biesmeijer \& Ermers (1999) actually found that some foragers keep visiting food sources even if a more profitable one is available, but also that a switching is possible after some time. It might be then that the bees in our experimental setup needed more time to switch to the control patch or a decrease of the food profitability happen as it is proposed by Schmidt et al. (2006). Switching to a new food source requires that foragers turn idle, receptive to be reactivated by successful foragers (Biesmeijer \& de Vries 2001) in our case, the foragers in the control patch. For pollination purposes this might mean a delay in pollen transfer between trees; but as long as foragers are spread over several food sources, there is the chance of switching and of pollen transfer between individual plants.

The low abundance of $S$. pectoralis on orange and lemon flowers in Oxkutzcab, Yucatán cannot be attributed to a lack of attraction to floral scents. Rather, the relatively recent introduction of the highly competitive honeybee in the study site can explain this. Even though some studies have demonstrated the absence of an effect of honeybees on native bee communities (Roubik 1983; Roubik et al. 1986; Pedro \& Camargo 1991; Wilms et al. 1996) studies on agricultural ecosystems are needed, since they represent a completely different and growing scenario. More important, they are actually considered either a threat (Klein et al. 2007; Priess et al. 2007; Klein et al. 2008), or an opportunity (Klein et al. 2008) to sustain stingless bee populations in the long term it all depends on how deep we know the interactions that occur in such man-modified environments.

\section{ACKNOWLEDGEMENTS}

We want to thank to CONACYT and UNACH for a scholarship given to Julieta Grajales Conesa. We also want to thank to MSc Javier Valle Mora for his support in statistic analysis 
and to the technicians of the Proyecto Abejas de Chiapas. This study was possible by the support of the FORDECYTCONACYT agreement no. 116306.

\section{REFERENCES}

Biesmeijer, J. C. \& H. de Vries. 2001. Exploration and exploitation of food sources by social insect colonies: a revision of the scout-recruit concept. Behavioral Ecology and Sociobiology 49: 89-99.

Biesmeijer, J. C. \& M. C. W. Ermers. 1999. Social foraging in stingless bees: how colonies of Melipona fasciata choose among nectar sources. Behavioral Ecology and Sociobiology 46: 129-140.

Chacoff, N. P. \& M. A. Aizen. 2006. Edge effects on flower-visiting insects in grapefruit plantations bordering premontane subtropical forest. Journal of Applied Ecology 43: 18-27.

Flamini, G.; P. L. Cioni \& I. Morelli. 2003. Use of solid-phase microextraction as a sampling technique in the determination of volatiles emitted by flowers, isolated flower parts and pollen. Journal of Chromatography 998: 229-233.

Flamini, G.; M. Tebano \& P. L. Cioni. 2007. Volatiles emission patterns of different plant organs and pollen of Citrus limon. Analytica Chimica Acta 589: 120-124.

Flores, S. \& I. Espejel 1994. Tipos de vegetación de la península de Yucatán. Universidad Autónoma de Yucatán, 136 p.

Gawleta, N.; Y. Zimmermann \& T. Eltz. 2005. Repellent foraging recognition across bee families. Apidologie 36: 325-330.

Goulson, D.; S. A. Hawson \& J. C. Stout. 1998. Foraging bumblebees avoid flowers already visited by conspecifics or by other bumblebee species. Animal Behavior 55: 199-206.

Grajales-Conesa, J.; V. Meléndez-Ramírez \& L. Cruz-López. 2009. Polinización de cultivos de naranja (Citrus sinensis) y limón (Citrus limon) en huertas de Oxkutzcab, Yucatán, México, p. 308-313. In: VI Congreso Mesoamericano sobre abejas nativas, Antigua Guatemala, Guatemala.

Grajales-Conesa J.; V. Meléndez-Ramírez \& L. Cruz-López. 2011. Aromas florales y su interacción con los insectos polinizadores. Revista Mexicana de Biodiversidad 82: 1356-1367.

Henning, J. A.; Y.-S. Peng; M. A. Montague \& L. R. Teuber. 1992. Honeybee (Hymenoptera: Apidae) behavioral-response to primary alfalfa (Rosales: Fabaceae) floral volatiles. Journal of Economic Entomology 85 : 233-239.

Jabalpurwala, F. A.; J. M. Smoot \& R. L. Rouseff. 2009. A comparison of citrus blossom volatiles. Phytochemistry 70: 1428-1434.

Klein, A.-M.; S. A. Cunningham; M. Bos \& I. Steffan-Dewenter. 2008. Advances in pollination ecology from tropical plantation crops. Ecology 89: 935-943.

Klein, A.-M.; B. E. Vaissière; J. H. Cane; I. Steffan-Dewenter; S. A. Cunningham; C. Kremen \& T. Tscharntke. 2007. Importance of pollinators in changing landscapes for world crops. Proceedings of the Royal Society B 274: 303-313.

Leal, W. S. 2005. Pheromone Reception, p. 341-360. In: S. Schulz (ed.). The Chemistry of Pheromones and other semiochemicals II. Berlin, Springer Berlin/Heidelberg, $\mathrm{p}$.

Lichtenberg, E. M.; V. L. Imperatriz-Fonseca \& J. C. Nieh. 2010. Behavioral suites mediate group-level foraging dynamics in communities of tropical stingless bees. Insectes Sociaux 57: 105-113.

McCabe, S. I. \& W. M. Farina. 2010. Olfactory learning in the stingless bee Tetragonisca angustula (Hymenoptera, Apidae, Meliponini). Journal of Comparative Physiology A Neuroethology Sensory Neural and Behavioral Physiology 196: 481-490.
McGregor, S. E. 1976. Insect pollination of cultivated crop plants. Washington, US Dept. Agric., 411 p.

Meléndez-Ramírez, V.; S. Magaña-Rueda; V. Parra-Tabla; R. Ayala \& J. Navarro. 2002. Diversity of native bee visitors of cucurbit crops (Cucurbitaceae) in Yucatán, México. Journal of Insect Conservation 6: $135-147$.

Nieh, J. C. 2004. Recruitment communication in stingless bees (Hymenoptera, Apidae, Meliponini). Apidologie 35: 159-182.

Pedro, S. R. de M. \& J. M. F. Camargo. 1991. Interactions on floral resources between the Africanized honey bee Apis mellifera L and the native bee community (Hymenoptera: Apoidea) in a natural "cerrado" ecosystem in southeast Brazil. Apidologie 22: 397-415.

Priess, J. A.; M. Mimler; A. M. Klein; S. Schwarze; T. Tscharntke \& I. Steffan-Dewenter. 2007. Linking deforestation scenarios to pollination services and economic returns in coffee agroforestry systems. Ecological Applications 17: 407-417.

Reichle, C.; S. Jarau; I. Aguilar \& M. Ayasse. 2010. Recruits of the stingless bee Scaptotrigona pectoralis learn food odors from the nest atmosphere. Naturwissenschaften 97: 519-524.

Roubik, D. W. 1995. Pollination of cultivated plants in the tropics. Food and Agricultural organization of the United States, $198 \mathrm{p}$.

Roubik, D. W. 1983. Experimental community studies: time-series tests of competition between African and Neotropical bees. Ecology 64: 971-978.

Roubik, D. W.; J. E. Moreno; C. Vergara \& D. Wittmann. 1986. Sporadic food competition with the African honey bee: projected impact on neotropical social bees. Journal of Tropical Ecology 2: 97-111.

Sánchez, D.; J. C. Nieh \& R. Vandame. 2008. Experience-based interpretation of visual and chemical information at food sources in the stingless bee Scaptotrigona mexicana. Animal Behavior 76: 407-414.

Sánchez, D.; J. C. Nieh; A. León \& R. Vandame. 2009. Food recruitment information can spatially redirect employed stingless bee foragers. Ethology 115: 1175-1181.

Schmidt, V. M.; R. Zucchi \& F. G. Barth. 2003. A stingless bee marks the feeding site in addition to the scent path (Scaptotrigona aff. depilis). Apidologie 34: 237-248.

Schmidt, V. M.; R. Zucchi \& F. G. Barth. 2006. Recruitment in a scent trail stingless bee (Scaptotrigona aff. depilis): changes with reduction but not with increase of the energy gain. Apidologie 37: 487-500.

Slaa, E. J.; J. Wassenberg \& J. C. Biesmeijer. 2003. The use of field-based social information in eusocial foragers: local enhancement among nestmates and heterospecifics in stingless bees. Ecological Entomology 28: $369-379$.

Slaa, E. J.; A. Cevaal \& M. J. Sommeijer. 1998. Floral constancy in Trigona stingless bees foraging on artificial flower patches: a comparative study. Journal of Apicultural Research 37: 191-198.

Slaa, E. J.; L. A. Sánchez Chávez; K. S. Malagodi-Braga \& F. E. Hofstede. 2006. Stingless bees in applied pollination: practice and perspectives. Apidologie 37: 293-315.

StatSoft. Statistica (data analysis software system). 2005. version 7.1, Tulsa, StatSoft Inc.,Available at: http://www.statsoft.com.

Villanueva-G, R.; D. W. Roubik \& W. Colli-Ucán. 2005. Extinction of Melipona beecheii and traditional beekeeping in the Yucatán peninsula. Bee World 86: 35-41.

Wilms, W.; V. Imperatriz-Fonseca \& W. Engels. 1996. Resource partitioning between highly eusocial bees and possible impact of the introduced Africanized honey bee on native stingless bees in the Brazilian Atlantic rainforest. Studies on Neotropical Fauna and Environment 31: 137-151.

Wu, Y.; P. Qiuhong; Q. Wenjun \& D. Changqing. 2009. Comparison of volatile profiles of Nine Litchi (Litchi chinensis Sonn) cultivars from Southern China. Journal of Agricultural and Food Chemistry 57: 9676-9681.

Received 26/4/2011; accepted 10/2/2012

Editor: Maria Cristina Gaglianone 